\title{
Analisis Situasi Gizi Buruk Pada Bayi Dan Balita di Kecamatan Woha Kabupaten Bima Nusa Tenggara Barat
}

\author{
Nuraini Fitri Irmah ${ }^{1(\mathrm{CA})}$, Nurislamyati ${ }^{2}$, Maya Febriyanti ${ }^{3}$ \\ ${ }^{1(\mathrm{CA})}$ Akademi Kebidanan Harapan Bunda Bima, Indonesia; enyadivayusuf@gmail.com \\ (Corresponding Author) \\ ${ }^{2,3}$ Akademi Kebidanan Harapan Bunda Bima, Indonesia
}

\begin{abstract}
This thesis aims to analyze the factors that cause malnutrition based on unicef theory that is eating unbalanced, Isa Diarrhea, Food Security, Pattern of Parenting, Sanitat ion, Health Service, Knowledge and Socio Culture. The method used is a qualitative approach that is a systematic scientific research on the parts and phenomena and their relationships. Data collection using observation and interview. Interviews were conducted on parents of malnourished infant infants, Village Midwives, Kaders, KIA Coordinators, Nutrition Corrector, Nursery, Religious and community leaders. This research can be concluded There are still many babies and toddlers who suffer from malnutrition in Woha Sub-district of Bima Regency caused by: Eating unbalanced that children eat less than 3 times a day with menu that does not vary. Ispa and Diarrhea Diseases are always a coexistent illness of malnutrition. Inadequate parenting pattern, that is there are not treated by parents but by his grandmother and exclusion of exclusive breastfeeding in children. Sanitation related to hand washing before meals and the discovery of drinking uncooked water. Immunization is not complete, on the frame of thinking there is no immunization, but in the study found many children who do not get complete immunization.
\end{abstract}

Keywords: Malnutrition; Infants; Toddlers

\begin{abstract}
ABSTRAK
Penelitian ini bertujuan untuk menganalisa faktor-faktor yang menyebabkan terjadinya gizi buruk berdasarkan teori Unicef yaitu makan tidak seimbang, Ispa Diare, Ketahanan pangan, Pola asuh, Sanitasi, Pelayanan Kesehatan, Pengetahuan dan sosial Budaya. Metode yang digunakan pendekatan kualitatif yaitu penelitian ilmiah yang sistematis terhadap bagian-bagian dan fenomena serta hubunganhubungannya. Pengumpulan data menggunakan observasi dan wawancara. Wawancara dilakukan pada orang tua bayi balita gizi buruk,Bidan Desa, Kader, Koordinator KIA,Korrdinator Gizi, KASI Gizi,, Tokoh agama dan tokoh masyarakat. Penelitian ini dapat disimpulkan Masih banyaknya bayi dan balita yang mengalami gizi buruk di Kecamatan Woha Kabupaten Bima disebabkan oleh: Makan tidak seimbang yaitu anak makan kurang dari 3 kali sehari dengan menu yang tidak bervariasi. Penyakit Ispa dan Diare yang selalu menjadi penyakit penyerta terjadinya gizi buruk. Pola asuh yang tidak memadai, yaitu ada yang dirawat bukan oleh orang tua tapi oleh neneknya serta tidak diberikannya ASI Ekslusif pada anak. Sanitasi yang berkaitan dengan cuci tangan sebelum makan serta ditemukannya minum air yang tidak dimasak. imunisasi yang tidak lengkap, pada kerangka berfikir tidak ada imunisasi, namun pada penelitian ditemukan banyak anak yang tidak mendapat imunisasi lengkap.
\end{abstract}

Kata Kunci: Gizi Buruk; Bayi; Balita

\section{PENDAHULUAN}

Tujuan utama pembangunan nasional adalah peningkatan kualitas sumber daya manusia (SDM) yang dilakukan secara berkelanjutan. Upaya peningkatan kualitas SDM dimulai dengan perhatian utama pada proses tumbuh kembang anak sejak pembuahan sampai mencapai dewasa muda. Pada masa tumbuh 
kembang ini, pemenuhan kebutuhan dasar anak seperti perawatan dan makanan bergizi yang diberikan dengan penuh kasih sayang dapat membentuk SDM yang sehat, cerdas dan produktif, (Unicef, 2012).

Gizi buruk merupakan bentuk terparah (akut) dari keadaan kurang gizi tingkat berat dan terjadi dalam waktu yang cukup lama, (Sunanto, 2014). Kejadian gizi buruk dikategorikan sebagai kejadian luar biasa (KLB), dimana setiap penemuan satu kasus baru gizi buruk harus segera dilaporkan oleh Puskesmas ke jenjang yang lebih tinggi, selain laporan ke pemerintah daerah. Hasil penelitian Riset Kesehatan Dasar (Riskesdas) secara nasional pada 2013, di Indonesia terdapat 23.703 .884 balita dan yang mengalami gizi buruk $19,6 \%$ atau 4.649 .933 balita, terjadi peningkatan jika dibandingkan dengan hasil Riskesdas tahun 2007 18,4\%. Gizi buruk di NTB berdasarkan data IPKM 2013 mencapai 25,73\%. Jumlah ini jauh lebih tinggi jika dibandingkan dengan rata-rata nasional 19,63\%.

Data Dinas Kesehatan Provinsi NTB tahun 2013 terdapat 646 penderita dengan 21 diantaranya meninggal, sedangkan tahun 2014 ditemukan 510 balita dengan gizi buruk dan 33 diantaranya meninggal, dan data tahun 2015 menunjukkan ada 339 balita di NTB mengalami gizi buruk yang 20 diantaranya meninggal, sehingga dari tahun 2013-2015 di NTB terdapat 1465 bayi balita dengan gizi buruk dan 74 diantaranya meninggal. Dari data diatas maka kejadian gizi buruk di NTB umumnya masih cenderung tinggi dengan tiap tahun kasus gizi buruk selalu ditemukan penderita-penderita baru dengan rentan usia 05 tahun. Tentu hal ini sangat memprihatinkan karena NTB pernah menjadi lumbung padi nasional dan 45,02\% penduduk bekerja di sector pertanian, (NTB dalam data, 2015)

Kabupaten Bima merupakan kabupaten yang paling timur di provinsi NTB terdiri 18 kecamatan. Tahun 2013 ditemukan 40 balita dengan gizi buruk dan terdapat 4 orang meninggal, tahun 2014 terjadi peningkatan penderita gizi buruk yaitu 44 orang dengan 2 meninggal dan tahun 2015 terdapat 29 balita yang mengalami gizi buruk 3 diantaranya meninggal. Masalah gizi baik bukan hanya tanggung jawab tenaga kesehatan saja, tetapi masalah gizi buruk ini merupakan kepentingan kita bersama dan semua pihak di setiap lapisan masyarakat, kepala desa, tenaga kesehatan, tokoh agama, pemilik industri, dan lainya, (Unicef Indonesia, 2015). Berdasarkan uraian diatas maka penulis tertarik untuk melakukan penelitian tentang Analisis Situasi Gizi Buruk pada Balita di Kecamatan Woha Kabupaten Bima NTB tahun 2020 .

\section{METODE}

Metode kualitatif digunakan untuk melengkapi penelitian terdahulu dengan bentuk kuantitatif. Metode ini digunakan agar mendapatkan informasi yang lebih mendalam mengenai analisis situasi gizi buruk pada balita di Kecamatan Woha Kabupaten Bima tahun 2020. Study kasus merupakan penelitian yang mendalam tentang individu, satu kelompok, satu organisasi, satu program kegiatan, dan sebagainya dalam waktu tertentu, yang dalam penelitian ini berkaitan dengan kejadian gizi buruk pada balita di Kecamatan Woha Kabupaten Bima NTB. Study kasus menghasilkan data yang selanjutnya dianalisis untuk menghasilkan teori. Variabel dalam penelitian ini antaralain: makan tidak seimbang, Ispa Diare, Ketahanan pangan, Pola asuh, Sanitasi, Pelayanan Kesehatan, Pengetahuan dan sosial Budaya.

Pengumpulan data menggunakan observasi dan wawancara. Wawancara dilakukan pada orang tua bayi balita gizi buruk,Bidan Desa, Kader, Koordinator KIA,Korrdinator Gizi, KASI Gizi,, Tokoh agama 
dan tokoh masyarakat. Tehnik pengumpulan data yang digunakan dalam penelitian ini adalah menggunakan purposive sampling atau pemilihan sampel berdasarkan tujuan, (Moleong, Rexy J. 2012). Dalam penelitian ini pemilihan informan didasarkan pada tujuan penelitian yaitu untuk menganalisa situasi gizi buruk pada balita di Kecamatan Woha Kabupaten Bima Nusa Tenggara Barat Tahun 2020.Pemilihan informan pada penelitian ini dilakukan berdasarkan kriteria yang telah ditetapkan peneliti sebelumnya

Peneliti menggunakan protokol wawancara sebagai panduan dalam mengajukan pertanyaan dan pertanyaan akan dikembangkan oleh peneliti setelah berada dilapangan. Tugas dari peneliti adalah aktif mendengar cerita atau jawaban dari responden dengan sambil melakukan perekaman dengan menggunakan recorder/handpone serta menghargai dan menindak lanjuti dari setiap jawaban informan.Tujuan dilakukan wawancara mendalam adalah agar peneliti mendapatkan informasi yang jelas dan rinci dari informan serta mendalam tentang situasi gizi buruk pada balita. Segala informasi yang didapatkan oleh peneliti darri informan akan dijamin kerahasiaannya.

\section{HASIL}

\section{Gizi Buruk}

Dari hasil observasi pada semua informan, informan menyambut dengan ramah dan bersedia untuk diwawancarai. Hasil observasi pada 7 anak yang mengalami gizi buruk berdasarkan ciri-ciri fisik yang dilihat maka dapat disimpulkan anak ada yang mengalami marasmus dan ada yang mengalami kwashiorkor. Dari hasil observasi anak informan A1, A3,A4, A5,dan A7 terlihat sangat kurus, rewel, mata cekung, dan perut cekung. Ciri tersebut merupakan ciri dari Marasmus. Sedangkan anak informan A2 dan A6 memiliki ciri edema atau bengkak terlihat jelas pada bagian wajah, rambut agak merah, dan perut terlihat buncit atau menonjol,ciri-ciri yang digambarkan oleh informan A2 dan A6 merupakan ciri dari Kwashiorkor.

Berdasarkan hasil wawancara yang dilakukan, faktor-faktor yang mempengaruhi terjadinya gizi buruk pada bayi dan balita di Kecamatan Woha Kabupaten Bima antara lain pola asuh, makan tidak seimbang, Ispa Diare, Imunisasi, dan pengetahuan. Untuk Pola Asuh, seluruh informan memiliki pola asuh yang kurang terhadap anak. Jawaban yang diberikan informan hampir sama. Semua informan tidak memberikan ASI ekslusif pada anaknya. Selain itu beberapa informan ada yang tidak merawat sendiri anaknya tapi diasuh oleh orang lain yaitu neneknya yaitu informan A3 dan A5. Dari 7 informan yang diwawancarai informan memberikan jawaban yang bervariasi. Informan mengungkapkan alasan mengapa tidak memberikan ASI Ekslusif pada anaknya.

Seluruh informan belum memberikan makanan seimbang untuk anaknya. Dari hasil observasi yang dilakukan saat peneliti bertanya sebagian besar antusias dalam menjawab pertanyaan dan menceritakan bagaimana pola makan anak serta pemenuhan nutrisi untuk anak. Dari 7 informan yang diwawancarai informan memberikan jawaban yang bervariasi. sebagian besar informan mengungkapkan kebiasaan makan anak yang membuat informan khawatir kecuali informan A3 dan A5. Seperti informan A1, informan mengungkapkan nafsu makan anaknya kurang dan anak tidak suka makan dan hanya minum susu saja, kalupun anak makan haanya 1 sendok saja. 


\section{Makan tidak Seimbang}

Dari hasil observasi yang dilakukan saat peneliti bertanya sebagian besar antusias dalam menjawab pertanyaan dan menceritakan bagaimana pola makan anak serta pemenuhan nutrisi untuk anak. Seluruh informan belum memberikan makanan seimbang untuk anaknya. Jawaban yang diberikan informan cukup bervariasi. Rata-rata informan merasa khawatir dengan kebiasaan makan anak yang buruk dan nafsu makan yang kurang sehingga menyebabkan informan menajadi malas untuk menyiapkan makanan anaknya.

Dari 7 informan yang diwawancarai informan memberikan jawaban yang bervariasi. sebagian informan mengungkapkan kebiasaan makan anak yang membuat informan khawatir. Informan menceritakan anak yang hanya makan 1-2 kali sehari dan porsinyapun sangat sedikit. Seperti informan A1, informan mengungkapkan nafsu makan anaknya kurang dan anak tidak suka makan dan hanya minum susu saja, kalupun anak makan haanya 1 sendok saja. Menu makan anak tidak bervariasi dan irforman dalam sehari memasak menu yang sama.

\section{Ispa Diare}

Berdasarkan hasil observasi yang dilakukan beberapa informan dengan tegas menjawab pertanyaan, dan sesekali sambil tersenyum. Beberapa informan dalam menangani penyakit yang menyertai anaknya memilih untuk menangani sendiri dirumah dengan cara tradisional maupun membeli obat yang ada di warung, karena masyarakat beranggapan anak akan dibawa ke fasilitas kesehatan jika penyakitnya tidak kunjung sembuh setelah ditangani sendiri dirumah. Beberapa informan mengatakan jika anaknya sakit maka yang lebih banyak mengurus adalah keluarga terdekat seperti neneknya, karena nenek ataupun orang yang lebih tua dianggap lebih berpengalaman dalam mengurus anak.

\section{Ketahanan Pangan}

Berdasarkan hasil observasi yang dilakukan, sebagian besar informan menjawab dengan penuh keyakinan dan semangat dan sebagian menjawab dengan sedikit tersenyum. Semua informan merasa tidak ada masalah dengan ketahanan pangan di Kecamatan Woha Kabupaten Bima yang berita dengan ketersediaan pangan dan akses untuk mendapatkan bahan pangan tersebut. Semua menganggap masalah karena selain ada pedagang yang datang setiap hari, masyarakat juga terbiasa menanam sayuran dipekarangan rumahnya yang sewaktu-waktu dapat dipetik untuk dijadikan sayur dan bahan makanan.

\section{Pola asuh}

Dari hasil observasi yang dilakukan saat peneliti bertanya sebagian besar antusias dalam menjawab pertanyaan dan menceritakan bagaimana pola asuh terhadap anak. Seluruh informan memiliki pola asuh yang kurang terhadap anak. Jawaban yang diberikan informan hampir sama. Semua informan tidak memberikan ASI ekslusif pada anaknya. Selain itu beberapa informan ada yang tidak merawat sendiri anaknya tapi diasuh oleh orang lain yaitu neneknya. 


\section{Sanitasi}

Berdasarkan hasil observasi yang dilakukan informan sebagian besar menjawab pertanyaan dengan jelas dan tanpa ragu, kadang sesekali sambil tersenyum. Sebagian besar informan masih mengganggap biasa prilaku-prilaku yang berpotensi untuk memunculkan infeksi ataupun penyakit pada anak, diantaranya mencuci tangan sebelum dan sesudah menyuapi anak, konsumsi air tidak dimasak serta pola makan anak yang itu sendiri yang maish suka jajan sembarangan. Sebagian besar informan saat ditanya apakah mencuci tangan terlebih dahulu sebelum menyuapi anak atau tidak menjawab tidak karena berbagai alasan ada yang lupa, ada yang sudah menganggap biasa, ada yang hanya tersenyumdan ada pula yang menjawab tidak sempat mencuci tangan karena saaat anaknya minta makan maka langsung disuapi saja.

\section{Pelayanan Kesehatan}

Berdasarkan hasil observasi yang dilakukan informan sebagian besar menjawab pertanyaan tanpa ragu-ragu dan dengan tegas menceritakan mengenai pelayanan kesehatan disekitar tempat tinggal mereka. Semua informan mengaku kendala tidak ada masalah dengan pelayanan kesehatan di Kecamatan Woha Kabupaten Bima. Petugas kesehatan sering datang diadakan setiap bulannya yang dihadiri oleh petugas gizi, imunisasi, dan bidan. Selain itu informan mengatakan akses pelayanan kesehatan dengan tempat tinggal mereka cukup dekat dan beberapa informan mengungkapkan bisa dijangkau dengan berjalan kaki.

\section{Imunisasi}

Hasil observasi sebagian informan dengan serius menjawab pertanyaan ini, dengan keyakinan tidak dipengaruhi siapapun walaupun awalnya informan mencoba mengingat-ingat. Terdapat 4 informan yang tidak memberikan imunisasi lengkap pada anaknya yaitu informan A1, A3, A4, dan A5.

\section{Pemberian Asi Ekslusif}

Hasil observasi sebagian informan dengan serius menjawab pertanyaan ini, dengan keyakinan tidak dipengaruhi siapapun walaupun awalnya informan mencoba mengingat-ingat. Terdapat 5 informan yang tidak memberikan ASI Ekslusif pada bayinya yaitu informan A2, A3, A4, A5, dan A7.

\section{Pengetahuan}

Temuan observasi saat wawancara informan terbuka saat wawancara, kadang hanya tersenyum saja sambil menggelengkan kepala ketika ditanya mengenai apa saja yang informan ketahui tentang gizi anak. Semua informan saat diwawancarai mengenai pengetahuannya tentang gizi anak informan menjawab seadanya apa yang informan ketahui. Informan mengatakan makanan yang bergizi itu cukup hanya dengan mengkonsumsi nasi dengan telur atau dengan ikan. Sementara sebagian informan mengatakan bahwa makanan bergizi untuk anak itu adalah jika anak diberikan nasi dengan telur, ikan, sayur dan kadang diberikan biscuit dan salome. 


\section{Sosial Budaya}

Berdasarkan hasil observasi kepada informan, saat ditanya mengenai budaya yang ada di lingkungannya yang berkaitan dengan nutrisi anak dan ASI ekslusif informan menjawab dengan penuh keyakinan dan tidak tampak adanya keraguan. Sebagian besar informan mengungkapkan bahwa sosial budaya yang ada disekitar lingkungan tempat tinggalnya tidak terlalu berpengaruh pada pemberian nutrisi anak, ASI ekslusif, maupun MP ASI. Sebagian informan menyatakan faktor budaya yang berkaitan dengan nutrisi anak tidak ada diwilayahnya, dan sebagian informan menyatakan factor budaya itu memang ada tapi informan tidak pernah melakukannya.

\section{PEMBAHASAN}

\section{Gizi Buruk di Kecamatan Woha}

Banyak hal yang menyebabkan gizi buruk di Kecamatan Woha masih saja terjadi meskipun berbagai upaya telah dilakukan diantaranya Makan Tidak Seimbang, ISPA Diare, Pola Asuh, Sanitasi, Imunisasi, Pengetahuan, dan Sosial Budaya. Makanan tidak seimbang untuk anak dan penyakit infeksi yang mungkin di derita anak. Anak yang mendapat makanan yang cukup tetapi diserang diare atau infeksi, nafsu makan menurun, akhirnya dapat menderita, gizi kurang. Sebaliknya, anak yang makan tidak cukup baik, daya tahan tubuh melemah, mudah diserang infeksi. Kebersihan lingkungan, tersedianya air bersih, dan berperilaku hidup bersih dan sehat akan menentukan tingginya kejadian penyakit infeksi. Secara garis besar gizi buruk disebabkan oleh asupan makanan yang kurang atau anak sering sakit, atau terkena infeksi. Asupan makanan yang kurang disebabkan oleh berbagai faktor, antara lain tidak tersedianya makanan secara adekuat, anak tidak cukup mendapat makanan bergizi seimbang, dan pola makan yang salah. Kaitan infeksi dan kurang gizi seperti layaknya lingkaran setan yang sukar diputuskan, karena keduanya saling terkait dan saling memperberat. Kondisi infeksi kronik akan menyebabkan kurang gizi dan kondisi malnutrisi sendiri akan memberikan dampak buruk pada sistem pertahanan sehingga memudahkan terjadinya infeksi, (Endang suwiji, 2006).

\section{Makan Tidak Seimbang}

Makan Tidak Seimbang merupakan penyebab langsung dari masalah gizi berdasarkan teori Unicef (2002). Pada penelitian semua orang tua memberikan makanan yang tidak seimbang untuk anaknya, hal ini disebabkan oleh pengetahuan dan pola asuh. Salah satu aspek kunci dalam pola asuh gizi adalah praktek penyusuan dan pemberian MP-ASI serta pemberian makanan. Praktek penyusuan dapat meliputi pemberian makanan, kolostrum, menyusui secara eksklusif dan praktek penyapihan. Praktek pola asuh gizi dalam rumah tangga biasanya berhubungan erat dengan faktor pendapatan keluarga, tingkat pendidikan dan pengetahuan ibu, (Amy Prahesti, 2001). Sebagian besar balita dengaan gizi buruk memiliki pola makan yang kurang beragam. Pola makanan yang kurang beragam memiliki arti bahwa balita tersebut mengkonsumsi hidangan dengan komposisi yang tidak memenuhi gizi seimbang. Berdasarkan dari keseragaman susunan hidangan pangan, pola makanan yang meliputi gizi seimbang 
adalah jika mengandung unsur zat tenaga yaitu makanan pokok, zat pembangun dan pemelihara jaringan yaitu lauk pauk dan zat pengatur yaitu sayur dan buah, (Tinneke, 2008).

\section{ISPA, Diare}

Hasil penelitian menunjukkan bahwa semua anak mengalami infeksi ISPA dan Diare sebagai penyakit penyerta gizi buruk yang dialami. Penyebab terjadinya ISPA dan Diare diantaranya pola asuh tidak memadai, sanitasi, dan kerangnya pengetahuan. Timbulnya gizi kurang tidak hanya karena makanan yang kurang, tetapi juga karena penyakit. Anak yang mendapatkan makanan cukup baik, tetapi sering diserang diare atau ISPA, akhirnya dapat menderita kurang gizi. Demikian juga pada anak yang makan tidak cukup baik, maka daya tahan tubuhnya akan melemah Dalam keadaan demikian mudah diserang infeksi yang dapat mengurangi nafsu makan, dan akhirnya dapat menderita kurang gizi.pada kenyataannya keduanya baik makanan dan penyakit infeksi secara bersama- sama merupakan penyebab kurang gizi, (Soekirman, 2009).

\section{Ketahanan Pangan}

Ketahanan pangan bukanlah suatu masalah yang menyebabkan gizi buruk. bahwa tidak ada masalah dengan ketersediaan pangan dan akses untuk mendapatkannya bisa dengan cara membeli atau memetik dari kebun. Sebuah rumah tangga dikatakan memiliki ketahanan pangan jika penghuninya tidak berada dalam kondisi kelaparan atau dihantui ancaman kelaparan, (Jokowarino, 2017).

\section{Pola Asuh}

Hasil penelitian menunjukkan bahwa semua informan belum memberikan pola asuh yaag memadai untuk anak. Hal ini disebabkan oleh kurangnya pengetahuan. Status gizi juga dapat dipengaruhi oleh praktek pola asuh gizi yang dilakukan dalam rumah tangga yang diwujudkan dengan tersedianya pangan dan perawatan kesehatan serta sumber lainnya untuk kelangsungan hidup, pertumbuhan dan perkembangan anak, (Zeitlin Marian, 2000). Praktek pola asuh gizi dalam rumah tangga biasanya berhubungan erat dengan faktor pendapatan keluarga, tingkat pendidikan dan pengetahuan ibu, (Amy Prahesti, 2001).

\section{Sanitasi}

Dalam penelitian ini sebagian besar informan belum menerapkan sanitasi yang benar pada anaknya. Aspek sanitasi yang ditekankan pada penelitian ini adalah kebiasaan mencuci tangan sebelum makan. Hal ini disebakan oleh kurangnya pengetahuan orang tua tentang bahaya tidak mencuci tangan sebelum makan.

\section{Pelayanan Kesehatan}

Di Kecamatan Woha Kabupaten Bima, Pelayanan Kesehatan bukanlah suatu masalah yang menyebabkan gizi buruk. Hal ini disebabkan oleh sudah tersedianya Poskesdes di tiap desa selain desa Waduwani namun akses ke Puskesmas cukup dekat, dan posyandu selalu diadakan tiap bulan. Peran pelayanan kesehatan telah lama diadakan untuk memperbaiki status gizi pelayanan kesehatan berpengaruh terhadap kesehatan dengan adanya penanganan yang cepat terhadap masalah kesehatan 
terutama masalah gizi. Pelayanan yang selalu siap dan dekat dengan masyarakat akan sangat membantu dalam meningkatkan derajat kesehatan (Bumi, 2005).

\section{Imunisasi}

Imunisasi merupakan salah satu hal yang berpengaruh terhadap terjadinya gizi buruk pada anak. Pada penelitian sebagian besar yaitu 4 anak tidak mendapatkan imunisasi lengkap. Hal ini disebabkan oleh kurangnya pengetahuan masyarakat tentang pentingnya memberikan imunisasi pada anak.

\section{ASI Ekslusif}

ASI Ekslusif merupakan salah satu hal yang berpengaruh terhadap terjadinya gizi buruk pada anak. Pada penelitian sebagian besar yaitu 5 anak tidak diberikan ASI Ekslusif. Hal ini disebabkan oleh kurangnya pengetahuan masyarakat tentang pentingnya ASI Ekslusif bagi ibu maupun anak. Air Susu Ibu (ASI) merupakan makanan terbaik untuk bayi. ASI sangat dibutuhkan untuk kesehatan bayi dan mendukung pertumbuhan dan perkembangan bayi secara optimal. Bayi yang mendapatkan ASI eksklusif akan memperoleh semua kelebihan ASI serta terpenuhi kebutuhan gizinya secara maksimal sehingga dia akan lebih sehat, lebih tahan terhadap infeksi, tidak mudah terkena alergi, dan lebih jarang sakit. Sebagai hasilnya, bayi yang mendapatka ASI secara eksklusif akan mengalami pertumbuhan dan perkembangan yang optimal, (Sulistyoningsih, 2011).

\section{Pengetahuan}

Pengetahuan sangat berpengaruh terhadap kejadian gizi buruk pada anak di kecamatan Woha Kabupaten Bima. Hal ini disebabkan oleh kurangnya pendidikan yang dimiliki oleh orang tua tersebut. Dengan pengetahuan yang kurang maka informan akan kesulitan dalam menyajikan makanan bergizi untuk anaknya, sehingga jika terjadi terus menerus dalam jangka waktu yang lama dan didukung oleh faktor lainnya maka gizi buruk pada anak dapat saja terjadi (Waluyo, 2004).

\section{Sosial Budaya}

Sosial budaya bukan merupakan penyebab terjadinya gizi buruk pada bayi dan balita dikecamatan Woha Kabupaten Bima. Dalam hal ini budaya yang berkembang ditengah masyarakat khususnya masyarakat woha Kabupaten Bima, memang diakui masih ada, namun karena berkembangnya tehnologi dan informasi serta didukung oleh peran tenaga kesehatan yang sangat aktif mengingatkan dan menginformasikan pesanpesan kesehatan kepada masyarakat.

\section{KESIMPULAN}

Masih banyaknya bayi dan balita yang mengalami gizi buruk di Kecamatan Woha Kabupaten Bima disebabkan oleh: (a) makan tidak seimbang yaitu anak makan kurang dari 3 kali sehari dengan menu yang tidak bervariasi; (b) penyakit Ispa dan Diare yang selalu menjadi penyakit penyerta terjadinya gizi buruk; (c) pola asuh yang tidak memadai, yaitu ada yang dirawat bukan oleh orang tua tapi oleh neneknya serta tidak diberikannya ASI Ekslusif pada anak; (d) sanitasi yang berkaitan dengan cuci tangan sebelum makan serta ditemukannya minum air yang tidak dimasak; (e) imunisasi yang tidak lengkap, 
pada kerangka berfikir tidak ada imunisasi, namun pada penelitian ditemukan banyak anak yang tidak mendapat imunisasi lengkap; (f) Asi ekslusif yang tidak diberikan pada anak. pada kerangka berfikir tidak ada ASI Ekslusif, namun pada penelitian ditemukan banyak anak yang tidak mendapat imunisasi lengkap; serta $(\mathrm{g})$ kurangnya pengetahuan orang tua tentang gizi yang baik untuk anak.

\section{DAFTAR PUSTAKA}

Achmadi dan Narbuko. (2005). Metodologi Penelitian. Jakarta: Bumi Aksara

Arhy Prahesti.2001. Kesehatan Reproduksi. Fitramaya. Yogyakarta

Badan Pusat Statistik NTB. 2016. Nusa Tenggara Barat Dalam Angka 2009-2015.

Endang Seuwiji, Pengantar Metodologi Peneletian, Jakarta : Mitra Wacana Media, 2006

Jokowarino. 2017. Upaya dan Bentuk Pelestarian Lingkungan

Moleong, Lexy J, (2012), Metodologi Penelitian Kuantitatif, Remaja Rosdakarya.

Riset Kesehatan Dasar (Riskesdas). (2013).

Soekirman,2009. Ilmu Gizi dan Aplikasinya. Jakarta : Direktorat Jendral Pendidikan Tinggi Departemen Pendidikan Nasional.

Sulis. 2011. Hubungan antara pengetahuan ibu tentang gizi Balita dan pola makan balita terhadap status Gizi balita di kelurahan srihardono Kecamatan pundong. Skripsi. Fakultas Teknik Universitas Negeri Yogyakarta

Sunanto, H. 2002. Cokelat, Budidaya, Pengolahan Hasil dan Aspek Ekonominya. Kanisius. Yogyakarta.

Tinneke P. 2008. Faktor-faktor yang mempengaruhi status gizi pada anak sekolah di daerah Jakarta. Thesis. Fakultas Kesehatan Masyarakat. Universitas Indonesia. Jakarta.

UNICEF. 2002. Pedoman Hidup Sehat. UNICEF. Jakarta

UNICEF. Ringkasan Kajian Gizi. Jakarta: Pusat Promosi Kesehatan - Kementerian Kesehatan RI; 2012.

UNICEF. Levels and trends in child mortality, Report 2015. In: Fund UNCs, editor. New York: 2015

Waluyo, L., 2004, Mikrobiologi Umum, Malang, UMM press

Zeitlin, M., H. Ghassemi., M. Mansour. 2000. Positive deviance in child nutritionwith emphasis on psychosocial and behavioural aspects and implications for development. Tokyo: The United Nations University. 